\title{
Mass transfer limitation of microbial growth and pollutant degradation
}

\author{
$\mathrm{H} \mathrm{Harms}^{1}$ and TNP Bosma ${ }^{2}$ \\ ${ }^{1}$ Swiss Federal Institute for Environmental Science and Technology (EAWAG), CH-8600 Dübendorf; ${ }^{2}$ Swiss Federal \\ Institute for Environmental Science and Technology (EAWAG), Limnological Research Center, CH-6047 Kastanienbaum, \\ Switzerland
}

Organic pollutants in soil can be removed by biotechnological treatment. A limitation of this technology is the efficiency of biodegradation. In many cases, the bulk of the pollution can be removed but residual pollutants remain and biodegradation rates are slower than expected from laboratory trials. Low biodegradation rates are often a result of limited accessibility of the pollutants. Major reasons for the reduced bioavailability are the unequal spatial distribution of microorganisms and pollutants and the retardation of substrate diffusion by the soil matrix. Mechanical mixing and the addition of surfactants are possible approaches to improve the bioavailability of pollutants during bioremediation. The application of flow-stop-flow techniques may be of help to overcome the limitations resulting from advective-diffusive transport mechanisms during pump-and-treat remediation of contaminant plumes.

Keywords: bioavailability; bioremediation; effective diffusivity; homogenization; mass transfer; surfactants

\section{Introduction}

Scope of the problem

The production and use of organic chemicals for more than one hundred years has caused the pollution of virtually all compartments of the environment. Nowadays, pollutants severely affect essential human activities such as food production and recreation, and may even threaten human health and reproductivity [7,28]. Many synthetic compounds accumulate in nature because the release rates exceed the rates of microbial and chemical degradation. Two major reasons for low biodegradation rates have been identified. (i) The biochemical potential to degrade a certain compound is limited. This is more likely the less the chemical resembles natural compounds $[5,89,116]$. (ii) The pollutant or other substances, eg appropriate electron acceptors, are unavailable to the microflora $[19,73,79]$. In this short review we discuss biological and environmental factors that govern the mass transfer of pollutants to microbes which possess the capacity to degrade them. Since limited mass transfer has not only been observed during bioremediation of polluted soil, this review also aims at making results from fields such as cell physiology, fermentation technology, and theoretical biology available to microbiologists and engineers.

Mass transfer limitation of cells and populations Chemicals seem to be available for microbes only when they are dissolved in water [31,51,84,109,114,124,125]. Consequently, nonaqueous phase liquids (NAPL) and solid compounds have to dissolve [117] and sorbed substrates have to desorb to become available $[42,51,75,93,106,110]$

Correspondence: H Harms, Swiss Federal Institute for Environmental Science and Technology (EAWAG), CH-8600 Dübendorf, Switzerland Received 31 October 1995; accepted 31 March 1996 as shown in Figure 1. Degradation of the rate-limiting chemical, which is usually the carbon source [6], by a single cell (microscopic scale) or a population of a given three-dimensional array (macroscopic scale) can be described by Michaelis-Menten kinetics [25]. The flux of a chemical through the membranes of cells $Q_{c}$ (microscopic: mass per time; macroscopic: mass per volume per time) is

$$
Q_{c}=Q_{\max } \frac{C_{c}}{K_{m}+C_{c}}
$$

where $Q_{\max }$ is the maximum flux, $C_{c}$ (mass per volume) is the concentration of chemical exposed to the cell surfaces and $K_{m}$ (mass per volume) is the cell surface concentration yielding $\frac{1}{2} Q_{\max }$. When the chemical is a carbon source, part

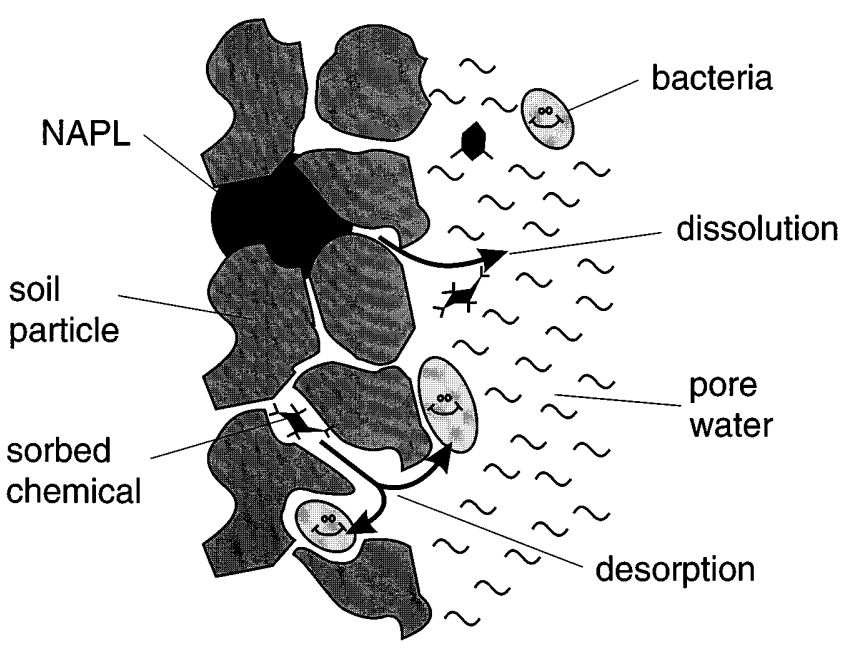

Figure 1 Distribution of bacteria and contaminants in a contaminated soil. Desorption and dissolution are indicated by arrows. NAPL, nonaqueous phase liquids. 
Mass transfer limitation of microbial growth $\mathrm{H}$ Harms and TNP Bosma

98

of the substrate transported into the cells is used to synthesize biomass. This can be accounted for by extending Equation 1

$$
Q_{c} Y=Q_{\max } Y \frac{C_{c}}{K_{m}+C_{c}}-b
$$

where $Y$ (numbers per mass) is the cell yield, $Q_{c} Y$ equals the growth rate $\mu$, whereas $Q_{\max } Y$ equals the maximum growth rate $\mu_{\max }$ [82]. The actual growth is biased by the rate constant $b$ (per time) that accounts for the fraction of substrate used to maintain the population by compensating for cell decay [55].

Equation 1 describes the flux into cells as a function of the concentration at the cell surface. However, the uptake of substrate reduces the concentration at the cell surface. $C_{c}$ is therefore determined by both the substrate uptake and the substrate transfer to the cells. For substrate diffusion, the flux to the cells $Q_{d}$ is

$$
Q_{d}=k\left(C_{d}-C_{c}\right)
$$

where $C_{d}$ is the distant aqueous concentration of the chemical and the mass transfer coefficient $k$ (microscopic: volume per time; macroscopic: per time) accounts for the capacity of the medium to let the chemical diffuse through. Appropriate terms for $k$ on the microscopic scale are: (i) $D_{\text {eff }} A / x$ for linear diffusion [64]; (ii) $D_{\text {eff }} 4 \pi R$ for radial diffusion [64]; and (iii) $k_{d} A_{s w}$ for the dissolution of solids or separate phase liquids [117]. $D_{\text {eff }}$ (area per time) is the effective diffusivity which may include effects of physical restriction and sorption on diffusion, $A$ is the area through which the diffusion takes place, $x$ is the distance, $R$ is the diameter of a cell, $k_{d}$ (distance per time) is the rate constant of dissolution, and $A_{s w}$ is the contact area between the chemical and water. Macroscopic $k$ values are obtained by dividing microscopic $k$ values by the volume of the living space occupied by the population. Equations 1 and 3 can be combined when steady state $Q_{d}=Q_{c}$ is assumed:

$$
\begin{aligned}
Q_{c} & =Q_{\max }\left(C_{d}+K_{m}+J\right)\left(1-\sqrt{\frac{1-4 C_{d} J}{\left(C_{d}+K_{m}+J\right)^{2}}}\right) / 2 J \\
J & =Q_{\max } / k
\end{aligned}
$$

Equation 4 was derived by Best [12]. The factor $J$ (mass per volume) equals the ratio of the degradative capacity of the cells to the transport capacity of the medium around the cells. Equation 4 represents a general concept for the consumption of substrate by microorganisms as a function of a distant substrate concentration. Figure 2 illustrates how the parameters included in Equation 4 determine the actual substrate flux. First, the mass transfer rate is a function of the cell parameters $Q_{\max }$ and $K_{m}$ which, in combination, influence $C_{c}$ (Figure 2a). Second, the distance between the substrate source and the microorganisms determines the slope of the diffusion gradient (Figure 2b). Third, properties of the chemical determine the distant substrate concentration (Figure 2c). Fourth, the geometry and the type of the medium between the substrate source and the microorganisms determines the effective diffusivity of the chemi- cal (Figure 2d). In the following we want to discuss the importance of these factors for the availability of pollutants in nature.

\section{Factors influencing mass transfer}

\section{Characteristics of the microorganisms}

Many microbial transporters and catabolic enzymes are regulated, ie they are only synthesized in response to the presence of a certain concentration of their substrate $[104,105]$. A concentration of $0.1 \mu \mathrm{M}$ induced the degradative pathway of $p$-hydroxybenzoate [36]. Enzymes for the catabolism of 3- and 4-chlorobenzoate by Acinetobacter calcoaceticus were induced at substrate concentrations above $1 \mu \mathrm{M}$ [88], while $50 \mu \mathrm{M}$ linuron was needed to induce the amidase that is necessary for a Gram-negative bacterium to cleave certain phenylurea herbicides [68]. In addition, microbes may need a continuous flux of substrate to keep enzyme synthesis turned on [54].

Mass transfer rates in non-sterile systems are faster than those in sterile systems [21]. This is because metabolically active microorganisms drive the diffusion by reducing the local concentrations of substrates, nutrients, and electron acceptors. Moreover, mass transfer rates seem to depend on the organism. Guerin and Boyd reported that Pseudomonas putida 17484 added to soil caused a flux of sorbed naphthalene that exceeded that driven by the strain NP-Alk or the desorption rate in a sterile control [48]. An explanation for these findings given by the authors was the attachment of Pseudomonas putida 17484 to the sorbent leading to the reduction of the naphthalene concentration close to the sorbent. Such an effect of the distance between cells and substrates has also been observed by others [50,51,90].

The ratio of $Q_{\max }$ to $K_{m}$ determines how much a cell reduces the substrate concentrations at its surface $[17,25,63,65,67]$. The reduction is more efficient the higher the uptake rate at low substrate concentrations. Law and Button defined this so-called specific substrate affinity $a^{\circ}{ }_{A}$ (volume per biomass and time) as the slope of the first order part of the activity-versus-concentration plot [67]. Koch combined the specific affinity of Escherichia coli with the substrate diffusion to the cell by expressing the efficiency of the solute uptake as the volume of solution cleared of substrate per unit time and per cell [63]. However, the cleared volume has no physical meaning, since it does not reflect the dynamic substrate resupply. Equation 4 can be used to calculate the mass transfer as a function of specific affinities of the cells and their distance to the substrate source. Figure 3 shows a calculation of linear diffusion driven by the dibenzofuran uptake of Sphingomonas $\mathrm{sp}$ HH19k [50] and of imaginary cells with 10-fold and 100fold lower $a^{\circ}{ }_{A}$ (due to 10 - and 100-fold higher $K_{m}$ ). When $C_{d}>>K_{m}$, the substrate flux is insensitive to $a_{A}^{\circ}$ and to the distance from the substrate (Figure $3 \mathrm{a}$ ). The flux becomes sensitive to both parameters only at $C_{d} \approx K_{m}$ (Figure $3 \mathrm{~b}$ ).

Often only a few of the indigenous microorganisms are able to degrade a pollutant added to the environment for the first time and efficient biodegradation will only occur after multiplication of these specialists $[2,4,102]$. However, growth of specialized organisms will only be favored in zones close to the contamination, where the flux of sub- 


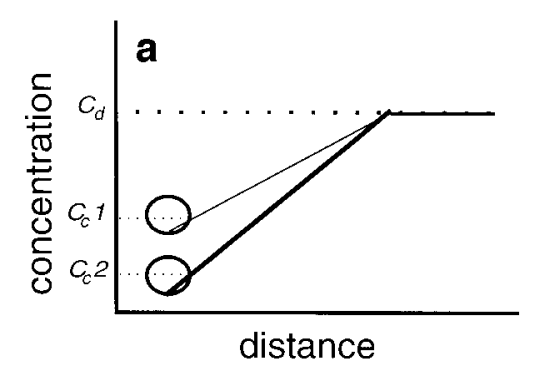

Mass transfer limitation of microbial growth $\mathrm{H}$ Harms and TNP Bosma
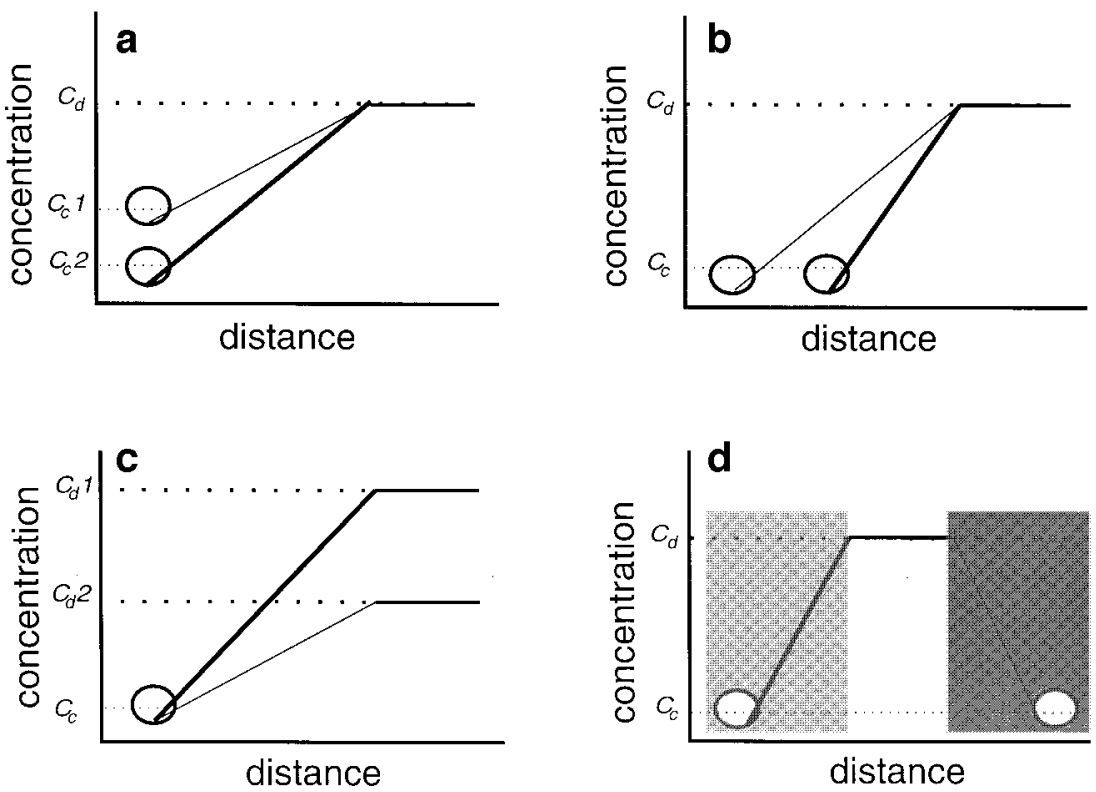

Figure 2 Schematic representation of factors governing the diffusive mass transfer of chemicals. More mass transfer is indicated by thicker lines. The circles represent bacteria. More mass transfer may result from the activity of cells with higher specific affinity, ie a lower cell surface concentration (a), from a shorter distance between substrate and cells (b), from higher distant substrate concentrations (c), and from less diffusion retardation (lighter background) by the medium between the substrate and the cells (d).

strate is sufficient to provide a nutritional advantage. Accordingly, limited substrate availability leads to a longer acclimation time by slowing the growth rate of the microbial population $[2,69,112]$. The rate constant $b$ is a measure of substrate needed to maintain a viable population. A microbial culture will grow until it reaches a density at which the substrate provision only fulfills its maintenance needs. The closer a culture comes to this density, the more of the substrate consumed will not form additional biomass. Alexander reported that under certain conditions in aqueous systems all the carbon was mineralized and little or none appeared in the biomass [6]. In one study, 93$98 \%$ of benzoate, benzylamine, aniline phenol, and 2,4 D added to lake water or sewage at concentrations below $300 \mu \mathrm{g}$ per liter was converted to $\mathrm{CO}_{2}$, and no carbon assimilation was observed during the mineralization of $24 \mathrm{ng}$ to $250 \mu \mathrm{g}$ of benzylamine per liter [111]. In another study, only $1.2 \%$ of the carbon source was converted to biomass [14].

In the 1960s, Jannasch postulated that the constant low concentration of carbon in the oceans was unavailable to support microbial growth and was therefore not mineralized [58]. Threshold concentrations observed during the remediation of subsurface environments were correlated with the maintenance needs of the microorganisms [22,92]. Theoretical considerations show that a drop of the substrate flux below the maintenance rate prompts the appearance of a threshold concentration below which the substrate is not further degraded. The value of this threshold is determined by $k$ and the maintenance coefficient [20]. Observations in our laboratory indicate that cells die when the substrate flux is below their maintenance requirements (H Harms, unpublished results).

\section{Spatial distribution of pollutants and microbes}

The distribution of a chemical and the microorganisms enters Equation 4 as one of the factors determining $k$. A pollutant may enter the soil as crystals [8], as a liquid [6], dissolved in an organic solvent [41,72], or sorbed to a solid phase [35]. The compound will, depending on its properties, either keep its physical state, dissolve in the soil water, sorb to the soil matrix, or evaporate in the gas-phase. In any case, the pollutant will be distributed non-randomly. Soil microorganisms occur mainly in an attached state $[34,108]$. Moreover, it was found that $60 \%$ of the soil bacteria were attached to particles covered with organic matter although these particles contributed only $15 \%$ to the total particle surface [46]. Upon multiplication microorganisms may form microcolonies, fostered by the low mobility of bacteria in soil. As a result of predation, soil bacteria most of which range in size between 0.5 and $0.8 \mu \mathrm{m}$ [30], occupy pores with a mean diameter of $2 \mu \mathrm{m}$, the so-called protected habitable space $[60,87]$. More than $50 \%$ of the total pore volume of a soil may consist of pores with diameters $<2 \mu \mathrm{m}$ [29] and 30\% of the total volume of some soils consists of pores with diameters less than $0.2 \mu \mathrm{m}$ [52]. Hence, $30-50 \%$ of the pores are not accessible, simply because they are too small for a bacterium to fit in. As a consequence, the mean distances between microcolonies and pollutants in soil may be relatively large.

Degradation of toxic compounds will occur only as the pollutant is transported away from the source with resultant dilution to subtoxic concentrations [6]. But even when the pollutant is non-toxic the degradation zone may not approach the pollutant source, since the diffusion of electron acceptors to the contaminant may be limiting [23]. Lyngkilde and Christensen identified a sequence of distinct 

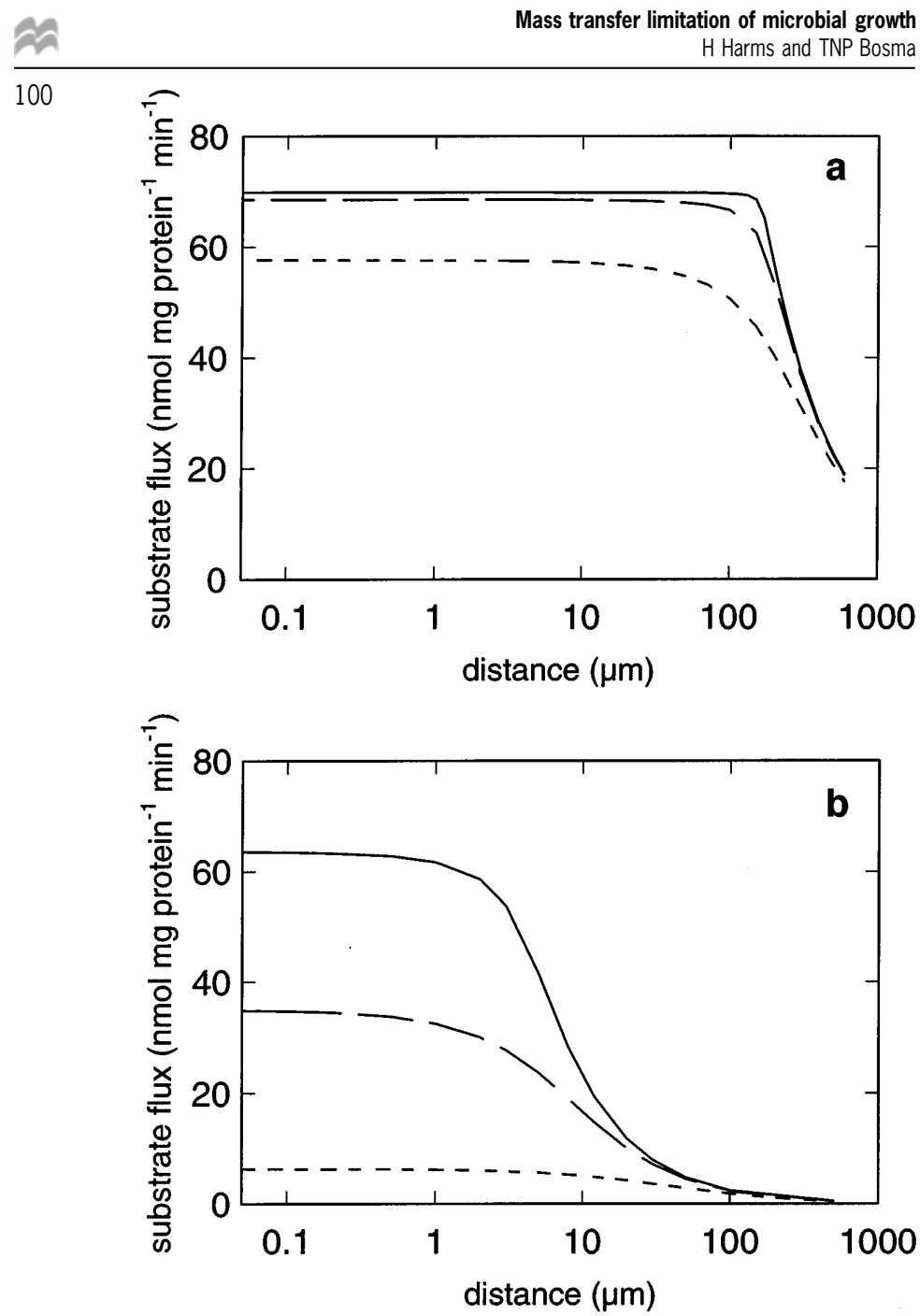

Figure 3 Calculations of the uptake-driven diffusive transfer of dibenzofuran to Sphingomonas sp HH19k (solid lines) and two imaginary bacterial strains only differing from HH19k by their ten-fold (long dashes) and hundred-fold (short dashes) lower specific affinities, as a function of the distance from the dibenzofuran source. Linear diffusion to the cells was assumed. $C_{d}$-values were set to the aqueous solubility of dibenzofuran at $28^{\circ} \mathrm{C}(32 \mu \mathrm{M}, \mathrm{a})$ and to $10 \times K_{m}$ of $\mathrm{HH} 19 \mathrm{k}(0.68 \mu \mathrm{M}, \mathrm{b})$, respectively.

methanogenic, sulfidogenic, ferrogenic, nitrate-reducing and aerobic zones in the plume below a landfill [73]. The high organic content close to the landfill had resulted in the depletion of all electron acceptors except carbon dioxide, while during dilution of the leachate the other electron acceptors successively became available again. Pollutants which are not subject to anaerobic degradation will remain intact until they reach the oxic zone.

Many microorganisms reduce the distance to the substrate source by adhering to non-aqueous phase liquids, solid substrates, or organic matter containing their substrate. Marshall and Cruickshank observed the partitioning of bacteria into an oil phase followed by perpendicular orientation of the cells at the oil-water interface [76]. Bacteria that grow on hydrocarbons often adhere to their substrates [83]. Bacterial adhesion to hydrocarbons is governed by the cell surface hydrophobicity and is, therefore, commonly used to distinguish between hydrophilic and hydrophobic bacteria [94]. Bacteria degrading palmitic acid and sterol attached to their solid substrates after having degraded the dissolved fraction [44,113]. In contrast, no growth was observed on biphenyl and phenanthrene crystals [109]. The importance of a close contact to substrates becomes obvious when the contact is suppressed. A Pseudomonas aeruginosa strain which did not produce rhamnolipids could not attach to hexadecane and no growth was observed on hexadecane during 2 days of incubation [62]. Non-adhesive mutants of other alkane-degrading bacteria could not grow on pure alkane, however growth could be re-established by the addition of an emulsifier [95]. A similar result was observed with bacteria attaching to heptamethylnonane containing the growth substrate hexadecane, where adhesion and growth could be suppressed by the nontoxic surfactant Triton X-100 [40]. Preventing the adhesion of yeasts to hydrocarbons by a surfactant also suppressed their activity [3,81]. Association to substrates is even more important when their consumption requires exoenzymes. Here the enzyme has to diffuse from the cell to the substrate and the product has to diffuse back to the cells. Sorbed methyl-coumarinyl-amide leucin was therefore only used by surface-associated microorganisms but not by free ones [47]. Scow and Alexander studied the spatial separation of cells and substrates by providing the substrates inside artificial aggregates which excluded the bacteria [99]. An increase in the volume of solution retained inside the beads resulted in slower initial mineralization rates and lower residual substrate concentrations.

In soils bacteria are barely mobile. When applied to soil surfaces they penetrate only $3-5 \mathrm{~cm} \quad[38,74]$. Goldstein et al suggested that adding bacteria to soil did not stimulate the degradation of 2,4-dichlorophenol or $p$-nitrophenol because the cells were immobile in the porous matrix [43]. It seems therefore, that degradation of distant pollutants in soils relies mainly on the transfer of the chemicals rather than on movement of bacteria.

A special case exists under advective flow, when bacteria are attached on the surfaces of particles and the substrate is dissolved in the mobile water phase. This situation may arise in contaminant plumes in aquifers. It was shown experimentally that under advective flow the diffusion of substrate to the cells limits the biodegradation rate [26,50]. The mass transfer to individual cells on the particles is determined by the liquid flow, the particle diameter, the cell density, and the microbial rate constants [50,91,123].

\section{Pollutant and matrix properties}

Chlorinated phenols, benzoic acids, and anilines are similar to natural organic compounds and can be incorporated in humus via oxidative coupling [16]. This reaction is catalyzed by peroxidases and phenol mono-oxygenases [77] and by inorganic materials, such as oxides and oxyhydroxides of iron [97], allophane [66], and silica and clay [118]. Phenolic lignin derivatives, such as vanillic acid, vanillin, ferulic and syringic acid, and man-made organics such as chlorinated phenols, naphtholic compounds and halogenated anilines can be cross-coupled with natural phenols in soil [11]. Chemicals which are linked to organic matter lose their original chemical and biological activity, and hence, are less bioavailable than the free compounds [15]. 
While the diffusivity of low-molecular weight chemicals in water is generally in the range of $1 \times 10^{-9} \mathrm{~m}^{2} \mathrm{~s}^{-1}$, diffusion in soils can be much slower. $D_{\text {eff }}$ enters Equation 4 as one of the factors determining $k$. Table 1 summarizes $D_{\text {eff }}$-values of pollutants that were observed in soils and sediments. Reported $D_{\text {eff }}$ up to 12 orders of magnitude lower than in pure water can be ascribed to the combined effects of: (i) physical barriers which restrict the diffusion to pores of small diameters and high tortuosities; and (ii) sorption, ie reversible physical or chemical interactions of the compounds with soil constituents. Mineral particles increase the diffusion path length and restrict the cross-sectional area through which the diffusion takes place. Sorption, in contrast, retards diffusion by transferring the solute from the aqueous phase into solid soil components. Sorption of hydrophobic contaminants in soil has been considered as partitioning between the water phase and the organic matter $[32,59,98,121]$ or as a physical binding to the organic matter [27]. Polar solutes like nitroaromatic compounds may adsorb specifically to mineral surfaces [49]. Smith et al explained the reduced degradation of quinoline in the presence of montmorrilionite and hectorite by the sorption of the compound to these clay minerals [103]. However, reduced degradation of nonsorbing acetate in the same system could only be explained by the physical impairment of the substrate uptake by clay particles covering the cells. Ou and Alexander showed that the presence of glass beads between chitin and degrading organisms delayed the degradation [85]. Adu and Oades showed that starch in micropores of artificial soil was unavailable [1] and Weissenfels et al concluded that scarcely available polycyclic aromatic hydrocarbons (PAH) are located in inaccessible sites within the soil [122].
Mass transfer limitation of microbial growth

$\mathrm{H}$ Harms and TNP Bosma

Slow diffusion through natural and artificial aggregates reduces the bioavailability of pollutants $[51,80,90,100]$. A sorption-retarded radial diffusion model [126] could explain the effect of aggregate size on $\alpha$-hexachlorocyclohexane $(\alpha-\mathrm{HCH})$ desorption and bioconversion rate [90]. Intraparticle diffusion may be a slow process which does not reach equilibrium within years $[9,10,24,45,90]$. The longer certain compounds are in contact with soil, the more resistant they become to desorption and degradation. In soils this has been found with chlorophenol [96], TCE [86], picloram [78], simazine [101], 1,2-dibromoethane [107], hexachlorobenzene [13], nitrophenol, and phenanthrene [53]. Steinberg attributed this so-called contaminant aging to progressive entrapment of the chemicals in microscopic pores [107]. Contaminant aging could be simulated in short time scales with 3-chlorodibenzofuran that was sorbed by Teflon particles [51].

Another kind of physical barrier is pore space filled with gas. The diffusivity of small molecules in gas is generally in the range of $1 \times 10^{5} \mathrm{~m}^{2} \mathrm{~s}^{-1}$ [119]. The effect of gas on $D_{\text {eff }}$ will therefore depend mainly on the Henry's law constant for the distribution between both phases. The mass transfer of volatile compounds such as naphthalene through the gas phase is favored as compared to the water phase. Therefore, naphthalene-degrading bacteria grew denser when the water content of their porous environment was lower (H Harms, unpublished results). Air-water interfaces act as reactive surfaces which accumulate hydrophobic chemicals [56]. Before mass transfer through unsaturated zones is in a steady state, part of the chemical will be lost to the multitude of air-water interfaces.

Table 1 Effective diffusivities of low-molecular weight chemicals

\begin{tabular}{|c|c|c|c|}
\hline Sorbate & System & $\begin{array}{l}\text { Effective diffusivities } \\
\left(\mathrm{m}^{2} \mathrm{~s}^{-1}\right)\end{array}$ & Ref \\
\hline $\begin{array}{l}\text { Low molecular weight } \\
\text { chemicals }\end{array}$ & pure water & $5 \times 10^{-10}-1 \times 10^{-9}$ & [120] \\
\hline $\begin{array}{l}\text { Low molecular weight } \\
\text { chemicals }\end{array}$ & air & $5 \times 10^{-6}-2 \times 10^{-5}$ & [119] \\
\hline$\alpha-\mathrm{HCH}$ & mixed soil suspensions & $5 \times 10^{-17}$ a & {$[90]$} \\
\hline Pentachlorobenzene & Charles River sediment & $<8.3 \times 10^{-15}$ a & [126] \\
\hline Pentachlorobenzene & North River sediment & $8.3 \times 10^{-16}$ a & [126] \\
\hline Pentachlorobenzene & soil & $2.5 \times 10^{-14 \mathrm{a}}$ & [126] \\
\hline 1,2,4-Trichlorobenzene & Charles River sediment & $3.3 \times 10^{-14 \text { a }}$ & [126] \\
\hline 1,4-Dichlorobenzene & Charles River sediment & $1 \times 10^{-13 \text { a }}$ & [126] \\
\hline $1,2,3,4$-Tetrachlorobenzene & Charles River sediment & $\begin{array}{l}2.0 \times 10^{-14 a, b} \\
8.3 \times 10^{-15 a, c}\end{array}$ & [126] \\
\hline 1,2,3,4-Tetrachlorobenzene & North River sediment & $\begin{array}{l}5.0 \times 10^{-15 \mathrm{a}, \mathrm{b}} \\
1.3 \times 10^{-14 \mathrm{a}, \mathrm{c}}\end{array}$ & [126] \\
\hline 1,2,3,4-Tetrachlorobenzene & soil & $1 \times 10^{-13 \mathrm{a}}$ & [126] \\
\hline $1,2,4,5$-Tetrachlorobenzene & sandy aquifer material & $\begin{array}{l}1.3 \times 10^{-11 \mathrm{a}, \mathrm{d}} \\
1.7 \times 10^{-13}\end{array}$ & [9] \\
\hline Perchloroethene & sandy aquifer material & $\begin{array}{l}1.4 \times 10^{-10 \mathrm{a}, \mathrm{d}} \\
9.2 \times 10^{-12}\end{array}$ & [9] \\
\hline 1,2-Dibromoethane & soil & $2-8 \times 10^{-21 \text { a }}$ & [107] \\
\hline Kepone & salt marsh sediment & $3.7 \times 10^{-16 \text { a }}$ & [33] \\
\hline
\end{tabular}

aDetermined in soil slurries.

${ }^{b}$ Determined during sorption.

${ }^{\mathrm{c}}$ Determined during desorption.

${ }^{\mathrm{d}}$ Differences were observed with different particle size classes. 
Mass transfer limitation of microbial growth H Harms and TNP Bosma

\section{Measures to improve mass transfer in soil}

\section{Homogenization}

Degradation rates can be enhanced by reducing the average distances between the cells and their substrates. This leads to faster substrate flux and allows maintenance of more cells. It is well accepted, that homogenization of soils promotes the degradation of sparsely mobile pollutants $[18,90]$. Zehnder and his co-workers studied the feasibility of bioremediation of a soil that had been contaminated with $\alpha$-HCH for more than 20 years $[8,37,57,90]$. Figure 4 summarizes the results of this study. Biodegradation was stimulated after the soil was dug out and put into lysimeters. Addition of nutrients or oxygen did not increase biotransformation proving that nutrient availability was not limiting. Also, no biodegradation was observed at concentrations below $150 \mathrm{mg} \mathrm{kg}^{-1}$ [37]. In contrast, a rigorous mixing of the soil breaking up the large soil particles resulted in an almost complete degradation of the $\alpha-\mathrm{HCH}$ within 2 weeks [90]. Biodegradation in these soil slurries was still desorption-limited since a pure culture isolated from the polluted soil completely mineralized the same amount of $\alpha-\mathrm{HCH}$ within 2 days [57]. Only a pulverization of soil particles liberated the $\alpha-\mathrm{HCH}$ trapped inside, increasing the biotransformation rates and decreasing the residual concentrations.

\section{Vapor extraction}

Soil vapor extraction (SVE) or bioventing makes use of the high Henry constants of pollutants such as chlorinated hydrocarbons. Air injection wells provide air to the subsurface and enhance air flow through the contaminated zone. The volatilized contaminant is removed through extraction wells. The efficiency of SVE arises from the high air flow rates which can be applied. Travis and MacInnes report on the fast removal of non-sorbed trichloroethylene (TCE) and perchloroethylene (PCE) from several sites [115]. However, when the pollutant had time to enter the interior of soil particles, SVE seems to lose its superiority over the water-based pump-and-treat technique. It was shown that for an aged TCE contamination, intraparticle transport limited the rate of TCE removal by SVE [45].

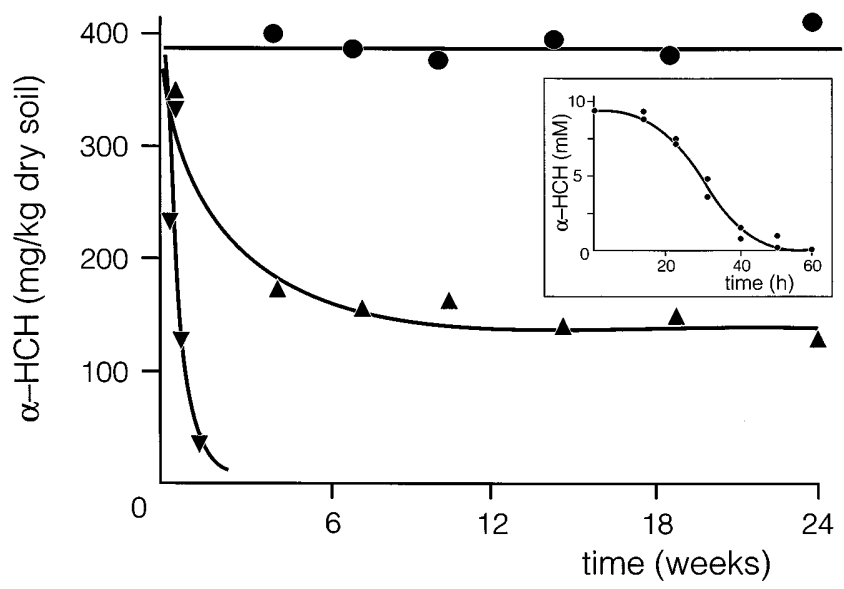

Figure 4 Biodegradation of $\alpha-\mathrm{HCH}$ in the field $(\bullet)$, in lysimeters $(\boldsymbol{\Delta})$, in laboratory slurries $(\boldsymbol{\nabla})$ and in pure culture (insert) (data from references 37,57 , and 90).

\section{Surfactants}

There is an ongoing discussion about the effectiveness of surfactants in bioremediation. For a summary of positive and negative effects of surfactants, the reader is referred to Liu et al [70]. Enhancement of biodegradation has usually been ascribed to the surfactant-mediated solubilization or emulsification of sorbed, crystalline or separate phase pollutants. Detrimental effects have been attributed to the toxicity of the surfactant, the prevention of bacterial adhesion to the substrate, or the preferred degradation of the surfactants. Typically, surfactant concentrations must be greater than the critical micelle concentration (CMC) before solubilization occurs [39], especially when some of the surfactant sorbs to soil [71], but some surfactants may increase the water pseudo-solubility of hydrophobic molecules below the CMC [61]. Surfactants do not increase the aqueous concentration of a compound, but introduce the socalled micellar pseudophase [70], which accumulates the chemical and is mobile. Therefore, it may be argued that the effectiveness of surfactants is mainly due to the homogenization of hydrophobic pollutants.

\section{In situ bioremediation}

Residual concentrations of pollutants will always remain after bioremediation of polluted soil, due to sorption and incorporation in organic matter. It is imaginable to first remove the mobile fraction of pollutant via a biological treatment. During this phase, both homogenization and the addition of surfactants may stimulate the biodegradation rate. However, the effect of homogenization is minor in later stages of in situ bioremediation. The residual pollutant is trapped inside soil aggregates which cannot be broken up by mechanical mixing. Therefore, diffusion within the micropores, retarded by sorption, is the limiting factor for biodegradation. It should be sufficient to monitor pollutants that are slowly leaching from the soil and to stimulate biotransformation by the addition of nutrients when a critical concentration is reached. Bioremediation can be stopped when the risk associated with the soil pollution is below acceptable limits. A similar approach would be feasible for contaminated groundwater. The application of flow-stopflow techniques would overcome the limitations resulting from advective-diffusive transport mechanisms during pump-and-treat remediation of contaminant plumes. New pollutions have to be treated biologically as soon as possible to achieve optimal results since long contact times between pollutants and soil have a negative effect on the success of bioremediation. However, priority should be given to the prevention of new pollutions.

\section{Acknowledgements}

We thank Mary E Power for comments concerning the manuscript.

\section{References}

1 Adu JK and JM Oades. 1978. Physical factors influencing decomposition of organic materials in soil aggregates. Soil Biol Biochem 10: 109-115.

2 Aelion CM, CM Swindoll and FK Pfaender. 1987. Adaptation to and 
biodegradation of xenobiotic compounds by microbial communities from a pristine aquifer. Appl Environ Microbiol 53: 2212-2217.

3 Aiba S, V Moritz, J Someya and KL Haung. 1969. Cultivation of yeast cells by using n-alkanes as the sole carbon source. I. Batch culture. J Ferm Technol 47: 203-210.

4 Alexander M. 1973. Nonbiodegradable and other recalcitrant molecules. Biotechnol Bioeng 15: 611-647.

5 Alexander M. 1981. Biodegradation of organic chemicals of environmental concern. Science 211: 132-138.

6 Alexander M. 1994. Biodegradation and Bioremediation. Academic Press, San Diego.

7 Auger JJ, M Kunstmann, F Czyglik and P Jouannet. 1995. Decline in semen quality among fertile men in Paris during the past 20 years. New Engl J Med 332: 281-285.

8 Bachmann A, W de Bruin, JVC Jumelet, HHM Rijnaarts and AJB Zehnder. 1988. Aerobic biomineralization of alpha-hexachlorocyclohexane in contaminated soil. Appl Environ Microbiol 54: 548554.

9 Ball WP and PV Roberts. 1991. Long-term sorption of halogenated organic chemicals by aquifer material. 1. Equilibrium. Environ Sci Technol 25: 1223-1237.

10 Ball WP and PV Roberts. 1991. Long-term sorption of halogenated organic chemicals by aquifer material. 2 Intraparticle diffusion. Environ Sci Technol 25: 1237-1249.

11 Berry DF and SA Boyd. 1985. Decontamination of soil through enhanced formation of bound residues. Environ Sci Technol 19: 1132-1133.

12 Best JB. 1955. The inference of intracellular enzymatic properties from kinetic data obtained on living cells. J Cell Comp Physiol 46: $1-27$.

13 Beurskens JEM, CGC Dekker, J Jonkhoff and L Pompstra. 1993. Microbial dechlorination of hexachlorobenzene in a sedimentation area of the Rhine river. Biogeochemistry 19: 61-81.

14 Boethling RS and M Alexander. 1979. Effects of concentration of organic chemicals on their biodegradation by natural microbial communities. Appl Environ Microbiol 37: 1211-1216.

15 Bollag J-M. 1991. Enzymatic binding of pesticide degradation products to soil organic matter and their possible release. Pestic Transf Prod 459: 122-132.

16 Bollag J-M and MJ Loll. 1983. Incorporation of xenobiotics into soil humus. Experientia 39: 1221-1231.

17 Boone DR, RL Johnson and Y Liu. 1989. Diffusion of the interspecies electron carriers $\mathrm{H}_{2}$ and formate in methanogenic ecosystems and its implications in the measurement of $K_{\mathrm{m}}$ for $\mathrm{H}_{2}$ or formate uptake. Appl Environ Microbiol 55: 1735-1741.

18 Bosma TNP. 1994. PhD thesis. Agricultural University, Wageningen, The Netherlands.

19 Bosma TNP, EMW Ballemans, NK Hoekstra, RAG te Welscher, JG MM Smeenk, G Schraa and AJB Zehnder. 1996. Biotransformation of organics in soil columns and an infiltration area. Ground Water 34: 49-56.

20 Bosma TNP, PJM Middeldorp, G Schraa and AJB Zehnder. 1996. Mass transfer limitation of biotransformation: quantifying bioavailability. Environ Sci Technol (in press).

21 Bouwer EJ and PL McCarty. 1982. Removal of trace chlorinated organic compounds by activated carbon and fixed-film bacteria. Environ Sci Technol 16: 836-843.

22 Bouwer EJ and PL McCarty. 1984. Modelling of trace organics biotransformation in the subsurface. Ground Water 22: 433-440.

23 Brunner W and DD Focht. 1984. Deterministic three-half-order kinetic model for microbial degradation of added carbon substrates in soil. Appl Environ Microbiol 47: 167-172.

24 Brusseau ML, RE Jessup and PSC Rao. 1991. Nonequilibrium sorption of organic chemicals: elucidation of rate-limiting processes. Environ Sci Technol 25: 134-142.

25 Button DK. 1985. Kinetics of nutrient-limited transport and microbial growth. Microbiol Rev 49: 270-297.

26 Caldwell DE and JR Lawrence. 1986. Growth kinetics of Pseudomonas fluorescens microcolonies within the hydrodynamic boundary layers of surface microenvironments. Microb Ecol 12: 299-312.

27 Calvet R. 1989. Adsorption of organic chemicals in soils. Environ Health Perspect 83: 145-177.

28 Carlsen E, A Giwercman, N Keiding and NE Skakkeback. 1992. Evi-
Mass transfer limitation of microbial growth

$\mathrm{H}$ Harms and TNP Bosma

dence for decreasing quality of semen during past 50 years. Br Med J 305: 609-613.

29 Cary JW and CW Hayden. 1973. An index for soil pore size distribution. Geoderma 9: 249-256.

30 Casida LE Jr. 1971. Microorganisms in unamended soil as observed by various forms of microscopy and staining. Appl Microbiol 21: 1040-1045.

31 Chakravatry M, PM Amin, HD Singh, JN Baruah and MS Iyengar. 1972. A kinetic model for microbial growth on solid hydrocarbons. Biotechnol Bioeng 14: 61-73.

32 Chiou CT 1989. Theoretical considerations of the partition uptake of nonionic organic compounds by soil organic matter. In: Reactions and Movement of Organic Chemicals in Soils (BL Sawhney and K Brown, eds), pp 1-29, Soil Science Society of America, Madison, WI.

33 Connolly JP. 1980. PhD Dissertation, University of Texas, Austin, Texas.

34 Costerton JW and HM Lappin-Scott. 1989. Behaviour of bacteria in biofilms. ASM News 55: 650-654.

35 Czuczwa JM and RA Hites. 1986. Airborne dioxins and dibenzofurans: sources and fates. Environ Sci Technol 20: 195-200.

36 DiMarco AA, B Averhoff and LN Ornston. 1993. Identification of the transcriptional activator $p o b \mathrm{R}$ and characterization of its role in the expression of $p o b \mathrm{~A}$, the structural gene for $p$-hydroxybenzoate hydroylase in Acinetobacter calcoaceticus. J Bacteriol 175: 44994506.

37 Doelman PL, H Haanstra, H Loonen and A Vos. 1990. Decomposition of alpha- and beta-hexachlorocyclohexane in soil under field conditions in a temporate climate. Soil Biol Biochem 22: 629-639.

38 Edmonds RL. 1976. Survival of coliform bacteria in sewage sludge applied to a forest clearcut and potential movement into groundwater. Appl Environ Microbiol 32: 537-546.

39 Edwards DA, RG Luthy and Z Liu. 1991. Solubilization of polycyclic aromatic hydrocarbons in micellar nonionic surfactant solutions. Environ Sci Technol 25: 127-133.

40 Efroymson RA and M Alexander. 1991. Biodegradation by an Arthrobacter species of hydrocarbon partitioned into an organic solvent. Appl Environ Microbiol 57: 1441-1447.

41 Efroymson RA and M Alexander. 1995. Reduced mineralization of low concentrations of phenanthrene because of sequestering in nonaqueous phase liquids. Environ Sci Technol 29: 515-521.

42 Ehrhardt HM and HJ Rehm. 1985. Phenol degradation by microorganisms adsorbed on activated carbon. Appl Microbiol Biotechnol 21: $32-36$.

43 Goldstein RM, LM Mallory and M Alexander. 1985. Reasons for possible failure of inoculation to enhance biodegradation. Appl Environ Microbiol 50: 977-983.

44 Goswami PC, HD Singh, SD Bhagat and JN Baruah. 1983. Mode of uptake of insoluble solid substrates by microorganisms. I: Sterol uptake by an Arthrobacter species. Biotechnol Bioeng 25: 29292943.

45 Grathwohl P and M Reinhard. 1993. Desorption of trichloroethylene in aquifer material: rate limitation at the grain scale. Environ Sci Technol 27: 2360-2366.

46 Gray TRG and D Parkinson. 1968. The Ecology of Soil Bacteria. Liverpool University Press, Liverpool, UK.

47 Griffith PC and M Fletcher. 1991. Hydrolysis of protein and model dipeptide substrates by attached and nonattached marine Pseudomonas sp strain NCIMB 2021. Appl Environ Microbiol 57: 21862191.

48 Guerin WF and SA Boyd. 1992. Differential bioavailability of soilsorbed naphthalene to two bacterial strains. Appl Environ Microbiol 58: 1142-1152.

49 Haderlein SB and RP Schwarzenbach. 1993. Adsorption of substituted nitrobenzenes and nitrophenols to mineral subsurfaces. Environ Sci Technol 27: 316-326.

50 Harms $\mathrm{H}$ and AJB Zehnder. 1994. Influence of substrate diffusion on degradation of dibenzofuran and 3-chlorodibenzofuran by attached and suspended bacteria. Appl Environ Microbiol 60: 2736-2745.

51 Harms $\mathrm{H}$ and AJB Zehnder. 1995. Bioavailability of sorbed 3-chlorodibenzofuran. Appl Environ Microbiol 61: 27-33.

52 Hassink JL, A Bouwman, KB Zwart and L Brussaard. 1993. Relationships between habitable pore space, soil biota and mineralization rates in grassland soils. Soil Biol Biochem 25: 47-55. 
53 Hatzinger PB and M Alexander. 1995. Effect of aging of chemicals in soil on their biodegradability and extractability. Environ Sci Technol 29: 537-545.

54 Heitzer A, K Malachowsky, JE Thonnard, PR Bienkowski, DC White and GS Sayler. 1994. Optical biosensor for environmental on-line monitoring of naphthalene and salicylate bioavailability with an immobilized bioluminescent catabolic reporter bacterium. Appl Environ Microbiol 59: 687-694.

55 Herbert D. 1959. Some principles of continuous culture. In: Recent Progress in Microbiology (Tuneval D, ed), pp 381-396, Almqvist \& Wiksell, Stockholm.

56 Hoff JT, D Mackay, R Gillham and WY Shiu. 1993. Partitioning of organic chemicals at the air-water interface in environmental systems. Environ Sci Technol 27: 2174-2180.

57 Huntjens JLM, W Brouwer, K Grobben, O Jansma, F Scheffer and AJB Zehnder. 1988. Biodegradation of alpha-hexachlorcyclohexane by a bacterium isolated from polluted soil. In: Contaminated Soil ' 88 (Wolf K, WJ van den Brink, FJ Colon, eds), pp 733-737, Kluwer Academic Publishers, Dordrecht, NL.

58 Jannasch HW. 1967. Growth of marine bacteria at limiting concentrations of organic carbon in seawater. Limnol Oceangr 12: 264-271.

59 Karickhoff SW, DS Brown and TA Scott. 1979. Sorption of hydrophobic pollutants on natural sediments. Water Res 13: 241-248.

60 Kilbertus G. 1980. Etude des microhabitats contenus dans les aggrégats du soil. Leur relation avec la biomass bactérienne et la taille des procaryotes présents. Rev Ecol Biol Soil 17: 543-557.

61 Kile DE and CT Chiou. 1989. Water solubility enhancements of DDT and trichlorobenzene by some surfactants below and above the critical micelle concentration. Environ Sci Technol 23: 832-838.

62 Koch AK, O Käpelli, A Fiechter and J Reiser. 1991. Hydrocarbon assimilation and biosurfactant production in Pseudomonas aeruginosa mutants. J Bacteriol 173: 4212-4219.

63 Koch AL. 1971. The adaptive responses of Escherichia coli to a feast and famine existence. Adv Microb Physiol 6: 147-217.

64 Koch AL. 1990. Diffusion-The crucial process in many aspects of the biology of bacteria. In: Advances in Microbial Ecology 11 (Marshall KC, ed), pp 37-70, Plenum Press, New York.

65 Koch AL and CH Wang. 1982. How close to the theoretical diffusion limit do bacterial uptake systems function? Arch Microbiol 131: 36-42.

66 Kyuma K and K Kamaguchi. 1964. Oxidative changes of polyphenols as influenced by allophane. Soil Sci Soc Am J 28: 371-374.

67 Law AT and DK Button. 1977. Multiple-carbon-source-limited growth kinetics of a marine coryneform bacterium. J Bacteriol 129: $115-123$.

68 Lechner U and G Straube. 1984. Influence of substrate concentration on the induction of amidases in herbicide degradation. Z Allg Mikrobiol 24: 581-584.

69 Lewis DL, HP Kollig and RE Hodson. 1986. Nutrient limitation and adaptation of microbial populations to chemical transformations. Appl Environ Microbiol 51: 598-603.

70 Liu Z, AM Jacobson and RG Luthy. 1995. Biodegradation of naphthalene in aqueous nonionic surfactant systems. Appl Environ Microbiol 61: 145-151.

71 Liu Z, S Laha and RG Luthy. 1991. Surfactant solubilization of polycyclic aromatic hydrocarbon compounds in soil-water suspensions. Wat Sci Technol 23: 475-485.

72 Luthy RG, DA Dzombak, CA Peters, SB Roy, A Ramaswami, DV Nakles and BR Nott. 1994. Remediating tar-contaminated soil at manufactured gas plant sites. Environ Sci Technol 28: 266A-277A.

73 Lyngkilde J and TH Christensen. 1992. Redox zones of a landfil leachate pollution plume (Vejen, Denmark). J Contam Hydrol 10: 273-289.

74 Madsen EL and M Alexander. 1982. Transport of Rhizobium and Pseudomonas through soil. Soil Sci Soc Am J 46: 557-560.

75 Manilal VB and M Alexander. 1991. Factors affecting the microbial degradation of phenanthrene in soil. Appl Microbiol Biotechnol 35: 401-405.

76 Marshall KC and RH Cruickshank. 1973. Cell surface hydrophobicity and the orientation of certain bacteria at interfaces. Arch Mikrobiol 91: 29-40.

77 Martin JP and K Haider. 1971. Microbial activity in relationship to soil humus formation. Soil Sci 111: 54-63.

$78 \mathrm{McCall}$ PJ and GL Agin. 1985. Desorption kinetics of picloram as affected by residence time in the soil. Environ Toxicol Chem 4: 37-44.

79 Mihelcic JR, DR Lueking, RJ Mitzell and JM Stapleton. 1993. Bioavailability of sorbed- and separate-phase chemicals. Biodegradation 4: 141-153.

80 Mihelcic JR and RG Luthy. 1991. Sorption and microbial degradation of naphthalene in soil-water suspensions under denitrification conditions. Environ Sci Technol 25: 169-177.

81 Mimura A, S Watanabe and I Takeda. 1971. Biochemical engineering analysis of hydrocarbon fermentation III. Analysis of emulsification phenomena. J Ferm Technol 49: 255-262.

82 Monod J. 1950. La technique de culture continue; théorie et applications. Ann Inst Pasteur 79: 390-410.

83 Nakahara T, LE Erickson and JR Gutierrez. 1977. Characteristics of hydrocarbon uptake in cultures with two liquid phases. Biotechnol Bioeng 19: 9-25.

84 Ogram AV, RE Jessup, L-T Ou and PSC Rao. 1985. Effects of sorption on biological degradation rates of $(2,4$-dichlorophenoxy)acetic acid in soils. Appl Environ Microbiol 49: 582-587.

$85 \mathrm{Ou} \mathrm{L-T}$ and M Alexander. 1974. Effect of glass microbeads on the microbial decomposition of chitin. Soil Sci 118: 164-167.

86 Pavlostathis SG and GN Mathavan. 1992. Desorption kinetics of selected volatile organic compounds from field contaminated soils. Environ Sci Technol 2: 532-538.

87 Postma J and JA van Veen. 1990. Habitable pore space and population dynamics of Rhizobium leguminosarum biovar trifolii introduced into soil. Microb Ecol 19: 149-161.

88 Reber HH. 1982. Inducibility of benzoate oxidizing cell activities in Acinetobacter calcoaceticus strain Bs 5 by chlorobenzoates as influenced by the position of chlorine atoms and the inducer concentrations. Eur J Appl Microbiol Biotechnol 15: 138-140.

89 Reineke W and H-J Knackmuss. 1978. Chemical structure and biodegradability of halogenated aromatic compounds: substituent effects on 1,2-dioxygenation of benzoic acid. Biochim Biophys Acta 542: $412-423$.

90 Rijnaarts HHM, A Bachmann, JC Jumelet and AJB Zehnder. 1990. Effect of desorption and intraparticle mass transfer on the aerobic biomineralization of $\alpha$-hexachlorocyclohexane in a contaminated calcareous soil. Environ Sci Technol 24: 1349-1354.

91 Rittmann BE and PL McCarty. 1980. Model of steady-state-biofilm kinetics. Biotechnol Bioeng 12: 2343-2357.

92 Rittmann BE, PL McCarty and PV Roberts. 1980. Trace-organics biodegradation in aquifer recharge. Ground Water 18: 236-243.

93 Robinson KG, WS Farmer and JT Novak. 1990. Availability of sorbed toluene in soils for biodegradation by acclimated bacteria. Water Res 24: 345-350.

94 Rosenberg M. 1991. Basic and applied aspects of microbial adhesion at the hydrocarbon:water interface. Crit Rev Microbiol 18: 159-173.

95 Rosenberg M and E Rosenberg. 1981. Role of adherence in growth of Acinetobacter calcoaceticus RAG-1 on hexadecane. J Bacteriol 148: 51-57.

96 Salkinoja-Salonen MS, PJM Middeldorp, M Briglia, RJ Valo, MM Häggblom, A McBain and JHA Apajalahti. 1989. Cleanup of old industrial sites. In: Advances in Applied Biotechnology (Kamely D, A Chakrabarty and G Omenn, eds), pp 347-365, Gulf Publishing Company, Houston, TX.

97 Scheffer F, B Meyer and EA Niederbudde. 1959. Huminstoffbildung unter katalytischer Einwirkung natürlich vorkommender Eisenverbindungen im Modellversuch. Z Pflanzenernährung Bodenkd 87: 26-44.

98 Schwarzenbach RP and J Westall. 1981. Transport of non-polar organic compounds from surface water to ground water: laboratory sorption studies. Environ Sci Technol 15: 1360-1367.

99 Scow KM and M Alexander. 1992. Effect of diffusion and sorption on the kinetics of biodegradation: experimental results with synthetic aggregates. Soil Sci Soc Am J 56: 128-134.

100 Scow KM and J Hutson. 1992. Effect of diffusion and sorption on the kinetics of biodegradation: theoretical considerations. Soil Sci Soc Am J 56: 119-127.

101 Scribner SL, TR Benzing, S Sun and SA Boyd. 1992. Desorption and bioavailability of aged simazine residues in soil from a continuous corn field. J Environ Qual 21: 115-120.

102 Shimp RJ and FK Pfaender. 1987. Effect of adaptation to phenol on biodegradation of monosubstituted phenols by aquatic microbial communities. Appl Environ Microbiol 53: 1496-1499. 
103 Smith SC, CC Ainsworth, SJ Traina and RJ Hicks. 1992. Effect of sorption on the biodegradation of quinoline. Soil Sci Soc Am J 56: 737-746.

104 Spain JC, PH Pritchard and AW Borquin. 1980. Effects of adaptation on biodegradation rates in sediments/water cores from estuarine and freshwater environments. Appl Environ Microbiol 40: 726-734.

105 Spain JC and PA van Veld. 1983. Adaptation of natural microbial communities to degradation of xenobiotic compounds: effects of concentration, exposure, time, inoculum, and chemical structure. Appl Environ Microbiol 53: 1010-1019.

106 Speitel JR and FA Digiano. 1987. The bioregeneration of GAC used to treat micropollutants. J Am Waterworks Ass 79: 64-73.

107 Steinberg SM, JJ Pignatello and BL Sawhney. 1987. Persistence of 1,2-dibromoethane in soils: entrapment in intraparticle micropores. Environ Sci Technol 21: 1201-1208.

108 Stotzky G. 1972. Activity, ecology, and population dynamics of microorganisms in soil. Crit Rev Microbiol 2: 59-126.

109 Stucki G and M Alexander. 1987. Role of dissolution rate and solubility in biodegradation of aromatic compounds. Appl Environ Microbiol 53: 292-297.

110 Subba-Rao RV and M Alexander. 1982. Effect of sorption on mineralization of low concentrations of aromatic compounds in lake water samples. Appl Environ Microbiol 44: 659-668.

111 Subba-Rao RV, HE Rubin and M Alexander. 1982. Kinetics and extent of mineralization of organic chemicals at trace levels in freshwater and sewage. Appl Environ Microbiol 43: 1139-1150.

112 Swindoll CM, CM Aelion and FK Pfaender. 1988. Influence of inorganic and organic nutrients on aerobic biodegradation and on the adaptation response of subsurface microbial communities. Appl Environ Microbiol 54: 212-217.

113 Thomas JM and M Alexander. 1987. Colonization and mineralization of palmitic acid by Pseudomonas pseudoflava. Microb Ecol 14: $75-80$.

114 Thomas JM, JR Yordy, JA Amador and M Alexander. 1986. Rates of dissolution and biodegradation of aromatic compounds. Appl Environ Microbiol 52: 290-296.
Mass transfer limitation of microbial growth

H Harms and TNP Bosma

115 Travis CC and JM MacInnes. 1992. Vapor extraction of organics from subsurface soils. Environ Sci Technol 26: 1885-1887.

116 van der Meer JR, WM de Vos, S Harayama and AJB Zehnder. 1992. Molecular mechanisms of genetic adaptation to xenobiotic compounds. Microbiol Rev 56: 677-694.

117 Volkering F, AM Breure and JG van Andel. 1993. Effect of microorganisms on the bioavailability and biodegradation of crystalline naphthalene. Appl Microbiol Biotechnol 40: 535-540.

118 Wang TSC, PM Huang, C-H Chou and J-H Chen. 1986. The role of soil minerals in the abiotic polymerization of phenolic compounds and formation of humic substances. In: Interactions of Soil Minerals with Natural Organics and Microbes (Huang PM and M Schnitzer, eds), pp 251-281, Soil Science Society of America, Madison, WI.

119 Warneck P. 1988. Chemistry of the Natural Atmosphere. Academic Press, San Diego, California.

120 Weast RC (ed). 1971. Handbook of Chemistry and Physics, 52nd edn. The Chemical Rubber Co, Cleveland, Ohio.

121 Weber WJ Jr, PM McGinley and LE Katz. 1991. Sorption phenomena in subsurface systems: concepts, models and effects on contaminant fate and transport. Water Res 25: 499-528.

122 Weissenfels WD, HL Klewer and J Langhoff. 1992. Adsorption of polycyclic aromatic hydrocarbons (PAH's) by soil particles-influence on biodegradability and biotoxicity. Appl Microbiol Biotechnol 36: 689-696.

123 Wilson EJ and CJ Geankoplis. 1966. Liquid mass transfer at very low Reynolds numbers in packed beds. Ind Eng Chem Fund 5: 9-15.

124 Wodzinski RS and D Bertolini. 1972. Physical state in which naphthalene and bibenzyl are utilized by bacteria. Appl Microbiol 23: 1077-1081.

125 Wodzinski RS and JE Coyle. 1974. Physical state of phenanthrene for utilization by bacteria. Appl Microbiol 27: 1081-1084.

$126 \mathrm{Wu} \mathrm{S}$ and PM Gschwend. 1986. Sorption kinetics of hydrophobic organic compounds to natural sediments and soils. Environ Sci Technol 20: 717-725. 